\title{
Deborah, Huldah, and Innibana
}

\section{Constructions of Female Prophecy in the Ancient Near East and the Hebrew Bible}

\author{
Jonathan Stökl (King’s College, London)
}

In this paper I examine three female prophets: Deborah (Judg 4-5), Huldah (2 Kgs 22 and $2 \mathrm{Chr}$ 34), and Innibana (ARM 26 205). The focus is on how female prophets are constructed in these texts and contexts. For the scholar of the ancient Near East, Huldah looks like a familiar character, with the twist that her authority is constructed differently from that of non-biblical ancient Near Eastern prophets. Deborah's combination of judge and prophet is even more noticeable in that regard. The construction of Deborah as a woman within Israelite society in that text is rather ambiguous. As I will argue, this ambiguity is characteristic of Second Temple construction of female prophecy.

\section{Introduction}

In this paper, I examine ancient Near Eastern (including biblical) texts that mention female prophets in order to analyze how these texts - and their authors - construct the identity of these female characters. I focus on texts rather than attempting to reconstruct a historical reality that may once have existed; I do not, in principal, deny our ability to approximate ancient historical realities. Here, however, I am above all interested in what the texts say about female prophets.

In this study, prophets, whether male or female, are understood as the human intermediaries used by deities in order to communicate with human addressees without the need for any further translation into human language. ${ }^{1}$ Additionally, I believe that there is good evidence that in ancient Near Eastern texts a distinction is being made between those whose main role is to prophesy and others who occasionally do so. ${ }^{2}$ The understanding of prophecy and the understanding of social roles naturally has an impact on which terms are understood here as technical terms for prophet. The understanding of what is

1 This definition follows M. Weippert, "Aspekte israelitischer Prophetie im Lichte verwandter Erscheinungen des Alten Orients," in Ad bene et fideliter seminandum: Festgabe für Karlheinz Deller zum 21. Februar 1987 (eds. U. Magen and G. Mauer; AOAT 220; Kevelaer/Neukirchen-Vluyn: Butzon \& Bercker/Neukirchener Verlag, 1988), 287-319, 289-90; M. Nissinen, "Prophecy and Omen Divination: Two Sides of the Same Coin," in Divination and Interpretation of Signs in the Ancient World (ed. A. Annus; OIS 6; Chicago: Chicago University Press, 2010), 341-51; J. Stökl, Prophecy in the Ancient Near East: A Philological and Sociological Comparison (CHANE 56; Leiden: Brill, 2012), 7-11.

2 See Stökl, Prophecy in the Ancient Near East, 7 n. 42, 50-63, 118-21. 
a technical term for a prophet, in turn, determines which individuals are identified in the texts as prophets. ${ }^{3}$ For Hebrew, this leaves me with the one title נביאה. Within the Akkadian texts different terms are used. I focus mainly on bearers of two titles: for Old-Babylonian Mari this is the apiltum, and for the Neo-Assyrian texts it is raggintu. ${ }^{5}$ In addition I adduce women who are attested as prophesying in the Neo-Assyrian texts. In my view, the primary role of the muhhûtum / mahhûtum, another title given to individuals in Akkadian texts, is that of a cult ecstatic, who occasionally prophesies, but not as a professional prophet. ${ }^{6}$ Thus, I focus on the two biblical female prophets Deborah and Huldah on the one hand, and on the other, representing ancient Near Eastern female prophets, Innibana, the appiltum from Mari, and a number of unnamed Neo-Assyrian female prophets.?

When comparing the literary texts from the Hebrew Bible with administrative texts from the ancient Near East it is important to remain aware of what we are doing. Some scholars would say that due to the difference in genre between the corpora the results are likely to be skewed. ${ }^{8}$ I do not deny the possibility of historical distortion but emphasize the aim of the paper to compare constructs of female prophets, not female prophecy as it once was.

3 This methodological decision relies on a non-value-laden understanding of the term "prophet." Different understandings of the term, from antiquity through more recent times, have led to suggestions that other biblical women should be considered prophets. For a discussion and further literature, see J. Stökl, “The מתנבאות of Ezekiel 13 Reconsidered," JBL 132 (2013): 61-76; idem, Prophecy in the Ancient Near East, 186-92.

4 None of the other prophetic titles is attested in the feminine form in the Hebrew Bible. The two main titles are ראה מה מה מה מה both G-participles of verbal roots meaning "to see." It is unclear whether the title איש אלהים should be understood as denoting a prophetic role, rather than a role like that of a "holy person" who is defined by proximity to the divine. In any case, the feminine form, אשת אלהים is not attested.

5 For a short discussion of the technical terms for prophets in the ancient Near East, see section 2, below. To make this study more legible I use anglicized plurals of Akkadian terms here, i.e., äpiltums rather than äpilätum, etc. For a more in depth discussion, see Stökl, Prophecy in the Ancient Near East, 38-64, 111-21.

6 On the distinction, see Stökl, Prophecy in the Ancient Near East, 38-64, 111-21.

7 A note on terminology: it has become common to use the expression "woman prophet" with the plural "women prophets." I use "female prophet" for the same purpose. The motivation for this is mainly a stylistic one. I will not use the formerly common feminine form "prophetess," as the English feminine ending "-ess" has over the years acquired a diminishing quality in some quarters, which I seek to avoid. Miriam, who would have made an interesting character to study for an enterprise such as this, is only mentioned tangentially, as Hanna Tervanotko has already analyzed this literary character to some depths. See H. Tervanotko, "Speaking in Dreams: The Figure of Miriam and Prophecy," in Prophets Male and Female: Gender and Prophecy in the Hebrew Bible, the Eastern Mediterranean, and the Ancient Near East (eds. J. Stökl and C.L. Carvalho; Ancient Israel and Its Literature 15; Atlanta: Society of Biblical Literature, 2013), 147-67; eadem, Denying Her Voice: The Figure of Miriam in Ancient Jewish Literature (JAJSup; Göttingen: Vandenhoeck \& Ruprecht, forthcoming).

8 See e.g., K. L. Sparks, Ancient Texts for the Study of the Hebrew Bible: A Guide to the Background Literature (Peabody: Hendrickson Publishers, 2005). 
Additionally, while there are few biblical female prophets, the amount of text we have about them, and especially Deborah, Miriam, and Huldah, is significant. The same cannot be said about female prophets in cuneiform texts, each of whom only has a small amount of text written about her. As a result, discussion of the characterization of female prophets in cuneiform texts will often include material written about male prophets, while in the discussion of biblical female prophets the material is such that it is not necessary to bring in biblical male prophets into the analysis.

I start by discussing the evidence for Innibana, and her ancient Near Eastern colleagues. The reason for this is two-fold. On the one hand, it provides an opportunity for some background to the discussion of female prophecy in biblical literature; on the other, the texts in question are less well known than the biblical texts. Additionally, I want to start the analysis of the construction of female prophets not at the point where female prophets are the exception (the Hebrew Bible) but rather in a context in which they are part of the normal way that prophecy is understood.

\section{Innibana and Her "Sisters"}

As mentioned above, Innibana represents all female prophets attested in the cuneiform record. ${ }^{9}$ Their number is considerable, and in the Neo-Assyrian texts they outnumber their male counterparts by quite a margin. ${ }^{10}$ In the cuneiform evidence for ancient Near Eastern prophecy, female prophets are well established. Indeed, if the female prophets in the Neo-Assyrian oracle collections were professional prophets and not "lay prophets," they were considerably more common in the Neo-Assyrian empire than their male counterparts.

At Mari three titles are used to refer to women who prophesy: äpiltum, muhhütum and qammatum. ${ }^{11}$ The title qammatum (meaning unclear) is used

9 Most of the prophetic texts from the ancient Near East are available in M. Nissinen, Prophets and Prophecy in the Ancient Near East: With Contributions by C. L. Seow and Robert K. Ritner (ed. P. Machinist; SBLWAW 12; Atlanta: Society of Biblical Literature, 2003) (a new edition with an extended list of texts is forthcoming). For a summary on ancient Near Eastern prophecy see E. Frahm, "Prophetie," Reallexikon der Assyriologie und Vorderasiatischen Archäologie 11 (2006): 7-11; J. Stökl, "Ancient Near Eastern Prophecy," in Dictionary of the Old Testament: Prophets (eds. J. Gordon McConville and M. J. Boda; Downer Grove, IL: InterVarsity, 2012), 16-24. For a longer discussion see Stökl, Prophecy in the Ancient Near East.

10 See, e. g., J. Stökl, “Ištar's Women, YHWH's Men? A Curious Gender-Bias in Neo-Assyrian and Biblical Prophecy," ZAW 121 (2009): 87-100; Nissinen, Prophets and Prophecy; J. Stökl, "Female Prophets in the Ancient Near East," in Prophecy and Prophets: Proceedings of the Oxford Old Testament Seminar (ed. J. Day; LHBOTS 531; London: T\&T Clark, 2010), 47-61; M. Nissinen, "Gender and Prophetic Agency in the Ancient Near East and in Greece," in Prophets Male and Female, 27-58.

11 On these three titles in both grammatical genders, see Stökl, Prophecy in the Ancient Near East, 38-62, 111-21. Another title is used only in the masculine form in connection with prophecy: assinnu. Because of the assinnu's cross-dressing, potentially connected to trans- 
in three texts, all of them referring to the same person and incident: ARM 26 197, 199 and 203. ${ }^{12}$ The matter at hand is a treaty with Ešnunna. The deity Dagan of Terqa informs the king through the qammatum that he should not trust the king of Ešnunna in this matter. The first of these three letters, ARM 26197 , is written by the king's sister, the female priest Inibšina, and it contains the following words: "beneath the straw water runs," as well as a divine promise to annihilate the king of Ešnunna in battle. ${ }^{13}$ The same sentence, probably a proverb, is also cited in ARM 26199 , a letter sent by Sammetar the governor of the city of Terqa where Inibšina is the priest of Dagan. This letter recounts the same event to the king as ARM 26197 but does not contain the oracle of divine support in war. Instead it features additional words describing Ešnunna as treacherous. A third text that mentions the expression is ARM 26 202, written by Kanisan, the father of the future governor of Terqa, Kibri-Dagan. In Kibri-Dagan's version as conveyed by his father, the oracle contains the saying and probably also an oracle of divine support, albeit in different words than Inibšina's letter contains. Additionally, the qammatum is not referred to by that title; instead a muhhütum is mentioned in connection with the oracle. If ARM 26202 does describe the same incident, which appears likely, then qammatum may be a different word for muhhütum or a subcategory of that term.

Muhhütums are attested relatively frequently at Mari. The term is the feminine form of muhhîm ("ecstatic"). Most scholars regard muhhûtum as a prophetic title. ${ }^{14}$ My own interpretation differs in that I interpret the available data to mean that they were cult ecstatics who, due to their primary function, were more pre-disposed to receiving divine messages than members of the wider public. ${ }^{15}$ Their main function was linked to lamentations in cultic rituals. Their precise function in these rituals is not clear, but at a certain place in the ritual the possibility is accommodated that they go into ecstasy; depending on whether they do, the musicians start singing a cultic lament. ${ }^{16}$ It

sexual behavior, in ritual texts, it is often thought that they represent a "third gender." On this question see now Nissinen, "Gender and Prophetic Agency"; J. Stökl, "'Gender Ambiguity' in Ancient Near Eastern Prophecy? A Re-Assessment of the Data Behind a Popular Theory," in Prophets Male and Female, 59-79; I. Zsolnay, "The Misconstrued Role of the Assinnu in Ancient Near Eastern Prophecy," in Prophets Male and Female, 81-99. See M. Nissinen and S. Svärd, "Constructing the Image of assinnu," in Gender, Methodology and the Ancient Near East (eds. A. Garcia-Ventura and S. Svärd; Winona Lake: Eisenbrauns, forthcoming).

12 ARM 26203 contains the word qammatum, but the tablet is in such a fragmentary state that little coherent meaning can be discerned.

13 For a thorough discussion see J. M. Sasson, "Water Beneath Straw: Adventures of a Prophetic Phrase in the Mari Archives," in Solving Riddles and Untying Knots: Biblical, Epigraphic, and Semitic Studies in Honor of Jonas C. Greenfield (eds. Z. Zevit, S. Gitin and M. Sokoloff; Winona Lake: Eisenbrauns, 1995), 599-608.

14 See, e. g., J.-M. Durand, Archives épistolaires de Mari I (ARM 26/1; Paris: ERC, 1988), 38688.

15 Stökl, Prophecy in the Ancient Near East, 51-57.

16 Most of the literature argues that this indicates a clear and strong relationship between prophecy and music at Mari-and consequently also in the Hebrew Bible. See, e.g., M. Nis- 
is noteworthy that among the attested named individual "ecstatics," women outnumber their male counterparts by some margin.

The title appiltum is the feminine G-participle of the verb apālu $(m)$ ("to answer, speak for") and the feminine equivalent of the masculine apilum. The traditional translation, "answerer," is not convincing, as they do not answer any questions. Consequently, I follow the current consensus and translate "spokesperson (of deity)." ${ }^{7}$ The feminine form of the term itself is only used in two texts, ARM 26 204, the text in which Innibana is mentioned, and FM 7 39, a letter by Nur-Sîn, Zimri-Lim's ambassador in Aleppo, in which NurSîn transmits a number of oracles from Aleppo to his king. As part of the letter he mentions that he had previously transmitted all oracles by male and female "spokespeople" to his king (lines 34-39). Innibana herself is attested only in one text: ARM 26 204. Like ARM 26 197, introduced above, this letter is sent by Inibšina. Only very little of Innibana's oracle is preserved, although it must have been originally quite substantial, filling lines 6-18 of the tablet. The oracle itself starts by warning Zimri-Lim that some of those who are close to him do not have his best interests at heart. Nothing further of the oracle is preserved, so we cannot draw further conclusions from its contents. ${ }^{18}$

As I have demonstrated elsewhere, it seems as if there is little or no difference between male and female "ecstatics" and the other male and female "spokespeople"-but there is a difference in the relative distribution: there are, relatively speaking, many äpilums (male), but only one named äpiltum (female). Conversely, the number of attested muhhütum (female) outstrips that of their male counterparts. Among those people who receive dreams and among those who prophesy but who are not otherwise involved in the cult, women comfortably outnumber men. ${ }^{19}$

sinen, "Biblical Prophecy from a Near Eastern Perspective: The Cases of Kingship and Divine Possession," in Congress Volume: Ljubljana 2007 (ed. A. Lemaire; VTSup 133; Leiden: Brill, 2010), 441-68, esp. 455-58; A. Lemaire, "Les textes prophétique de Mari dans leur relations avec l'Ouest," in Amurru 1: Mari, Ébla et les Hourrites: Dix ans de travaux, Actes du colloque international (Paris, mai 1993) (ed. J.-M. Durand; Paris: Éditions Recherche sur les civilisations, 1993), 427-38, 431. While the link between music to provoke trance and prophetic oracles is clearly established in $2 \mathrm{Kgs} 3: 15$, it is not attested in the ritual texts from Mari (FM 32 and FM 3 3); see Stökl, Prophecy in the Ancient Near East, 211-15. For FM 32 and FM 3 3, see J.-M. Durand and M. Guichard, "Les rituels de Mari," in Florilegium marianum III: Recueil d'études à la mémoire de Marie-Thérèse Barrelet (eds. D. Charpin and J.-M. Durand; Mémoires de N.A.B. U. 4; Supplément à N.A.B.U. 1997 no. 2; Paris: SEPOA, 1997), 19-78.

17 See also the discussion in Stökl, Prophecy in the Ancient Near East, 38-43.

18 The oracles start with the following words before the break: "Zimri-lim - until 'his' thieves, his enemies who [c]ircle around him..." The text is very fragmentary and so we do not know what the deity is suggesting Zimri-Lim wait for, but presumably the oracle contains a promise to help Zimri-Lim against the enemies in his inner circle. For a similar Neo-Assyrian message see SAA 9 1.7, an oracle delivered to the queen-mother promising her support for her son against conspirators.

19 See J. Stökl, "The Role of Women in the Prophetical Process in Mari: A Critique of Mary Keller's Theory of Agency," in Thinking Towards New Horizons: Collected Communications 
Innibana is introduced like her male counterparts, and her oracle is reported like theirs. This suggests that the gender of "spokespeople" does not appear to have made much of a difference with regard to their prophetic function. The same appears to be the case for "ecstatics." However, in a recent study, Esther Hamori has shown that prophetic oracles transmitted by women, irrespective of their title, were far more likely to be accompanied by their "hair and hem" (šărtum u sissiktum).$^{20}$ We know that in other cases, "hair and hem" were used to perform extispicy to establish whether someone was guilty of an offence or whether he was simply ill. ${ }^{21}$ This indicates that in the context of prophecy, "hair and hem" were used to double-check prophetic oracles; it is not entirely clear whether the speaker of the oracle or the oracle itself are checked, but in light of ARM 26229 the latter seems more probable. ${ }^{22}$ I agree with Hamori that overall the data suggests that the messages of women were much more likely to be checked than those of men. However, I suggest that we need to be careful with our conclusions: Innibana is the only individual female "spokesperson" who is attested. The fact that her message is checked does not say anything about whether this happened to other female "spokespeople" on a regular basis. The evidence that the messages of female "ecstatics" were checked more often than those of their male counterparts seems relatively strong. But with only one text it is difficult to uphold the distinction, as it could be coincidence that the one oracle by a female "spokesperson" that we have happens to involve her message being checked. By the same measure my previous assertion that there is no difference between male and female "spokespeople" has to be qualified as well. Until additional texts are found which shed further light on female prophets in Mari, our analysis must remain preliminary.

to the XIX ${ }^{\text {th }}$ Congress of the International Organization for the Study of the Old Testament, Ljubljana 2007 (eds. H. M. Niemann and M. Augustin; BEATAJ 55; Frankfurt am Main: P. Lang, 2008), 173-88.

20 E. J. Hamori, "Verification of Prophecy at Mari," WO 42 (2012): 1-22.

21 OBTR 65, see S. Dalley, C. B. F. Walker and J. D. Hawkins, The Old Babylonian Tablets from Tell al Rimah (London: British School of Archaeology in Iraq, 1976), 64-65.

22 ARM 26229 reports that a woman called Ayala had a dream in which two women appear to quarrel about the high-priesthood. Irrespective of the content of the dream, the author of the letter - whose name is sadly not preserved - reports that he has checked whether the dream was an ominous dream by means of birds and found that the dream was indeed ominous; see A. Zgoll, Traum und Welterleben im antiken Mesopotamien: Traumtheorie und Traumpraxis im 3. - 1. Jahrtausend v. Chr. als Horizont einer Kulturgeschichte des Träumens (AOAT 333; Münster: Ugarit-Verlag, 2006), 353-62. On this interpretation of the checking, see already D. Charpin, "Le contexte historique et géographique de prophéties dans les textes retrouvés à Mari," BCSMS 23 (1992): 21-31, 29-30. ARM 26 229: 20-21 reads "may my lord check it [the dream]." In ARM 26204 it is not entirely clear whose hair and hem are sent along, but I understand lines 16-18 ("now, I give you my hair and hem - may they be clean") still to be part of Innibana's message that is quoted in Inibšina's letter. Otherwise lines 19-21 ("now, herewith I send the hair and the fringe to My-Star [Zimri-Lim's nickname, used by close family members]") are difficult to understand. See the discussions in Hamori, "Verification of Prophecy at Mari," 2-4; Stökl, Prophecy in the Ancient Near East, $81-86$. 
In the Neo-Assyrian texts, female prophets outnumber their male colleagues. However, for the vast majority of NA prophets we do not have a title and it is uncertain whether we should simply understand all the speakers of the oracles in the oracle collections edited by Simo Parpola as raggimus and raggintus (male and female "proclaimers"), or whether some of the oracles would have been pronounced either by other religious specialists or by individuals not directly involved in the cult. ${ }^{23}$ There is also a lively debate as to whether some of the individuals mentioned in the texts were understood in antiquity as performing a third-gender role, whether they fitted into a binary gender system, albeit with biological and social gender non-aligned, or whether the underlying issue is one of spelling and grammar. ${ }^{24}$ The sources certainly do not indicate any form of prejudice against women who prophesy; male and female prophets are treated in the same way.

Like in the texts from Mari, what is preserved about the actions of prophets are most often their words. ${ }^{25}$ Likewise we have few reports of the actions of prophets instead of their words. One Neo-Assyrian example in which we see a raggintu on a royal mission is SAA $1337 .{ }^{26}$ This text is a letter by Adad-ahuiddina to his king, Esarhaddon. He reports that the raggintu Mulissu-abu-ușri had brought the king's (ceremonial?) clothes to Babylon, and that she had pronounced an oracle in the temple, regarding the royal throne. ${ }^{27}$ Sadly, the tablet is broken directly after this so that we do not know how the oracle continued

23 For the texts, see S. Parpola, Assyrian Prophecies (SAA 9; Helsinki: Helsinki University Press, 1997).

24 See most recently Nissinen, "Gender and Prophetic Agency"; Stökl, "Gender Ambiguity." On the wider issue see also Zsolnay, "The Misconstrued Role of the Assinnu"; Nissinen and Svärd, "Constructing the Image of assinnu," and the literature cited there.

25 More precisely, the words that ancient scribes wrote down. Many Neo-Assyrian prophetic texts are even further removed from the prophets' mouths. In Old-Babylonian Mari most prophetic texts come from reports in letters sent by officials to the king. Many Neo-Assyrian texts are archival copies of oracles, which means that they would have been copied from other text carriers, such as reports in letters. On the process, see M. J. de Jong, Isaiah Among the Ancient Near Eastern Prophets: A Comparative Study of the Earliest Stages of the Isaiah Tradition and the Neo-Assyrian Prophecies (VTSup 117; Leiden: Brill, 2007), 171-72. The argument that these oracle reports and archival copies should not be mistaken for ipsissima verba is made persuasively by K. van der Toorn, "Old Babylonian Prophecy between the Oral and the Written," JNSL 24 (1998): 55-70; idem, "From the Oral to the Written: The Case of Old Babylonian Prophecy," in Writings and Speech in Israelite and Ancient Near Eastern Prophecy (eds. E. Ben Zvi and M. H. Floyd; SBLSymS 10; Atlanta: Society of Biblical Literature, 2000), 219-34.

26 S. W. Cole and P. Machinist, Letters from Priests to the Kings Esarhaddon and Assurbanipal (SAA 13; Helsinki: Helsinki University Press, 1998), 36-37; see also Nissinen, Prophets and Prophecy, 167-68.

27 This letter and the oracle likely stand in connection with a substitute king ritual, as also mentioned in SAA 10 189. It is possible but not certain that this text was written in the context of the Sasî affair, on which see now E. Frahm, "Hochverrat in Assur," in AssurForschungen: Arbeiten aus der Forschungsstelle "Edition literarischer Keilschrifttexte aus Assur" der Heidelberger Akademie der Wissenschaften (eds. S. M. Maul and N. P. Heeßel. Wiesbaden: Harrassowitz, 2010), 89-137. 
and how it is related to the end of the report by Adad-ahu-iddina. What this text shows, however, is that a raggintu could be sent out with highly significant cultic items and could be expected to bring them quite a distance to Babylon.

SAA 9 7, another text that preserves the name of a Neo-Assyrian raggin$t u$, does not have a real introduction. ${ }^{28}$ Mullissu-kabtat is introduced as the prophet who spoke the following oracle, and then the oracle begins. The oracle itself contains a number of exegetical cruxes that are not easily solved. What is clear is that it is an oracle in support of king Aššurbanipal. It starts with the famous "fear not" formula also familiar from biblical texts ${ }^{29}$ and goes on to promise Aššurbanipal continuous control over the Neo-Assyrian Empire, as well as military success against Elam and Egypt, two traditional enemies to the East and Southwest, and it finishes with promises of divine support and supplication. ${ }^{30}$

As far as we can see from the ancient Near Eastern evidence, female - and male - prophets speak the words of deities to their human addressees. There appears to be a gender imbalance in the Mari evidence: in the texts available to us, most "spokespersons" of deities are men, while with "ecstatics" the gender distribution is more even, and among people not involved in the cult, women predominate. This suggests that access to the title apiltum ("spokesperson") may have been restricted to men in some sense. ${ }^{31}$

In the way male and female prophets carried out their prophetic function, however, there appears to be little difference - with the possibility that female prophets' messages were checked more often. This does not necessarily imply that female prophets would be trusted less. Instead it could be related to the fact that most prophetic messages that have survived from Mari are not uttered by "spokespeople," but instead by other, primarily non-prophetic religious specialists and "lay people."

\section{Hebrew Bible}

Having looked at the way that female (and male) prophets are portrayed in texts from Old Babylonian Mari and to some extent Neo-Assyrian Nineveh, in the following discussion the focus is on the construction of female prophecy in the Hebrew Bible. First I will discuss the portrayal of Huldah, followed

28 Parpola, Assyrian Prophecies, 38-39; Nissinen, Prophets and Prophecy, 126-28.

29 On the "fear not" formula see M. Nissinen, "Fear Not: A Study on an Ancient Near Eastern Phrase," in The Changing Face of Form Criticism for the Twenty-First Century (eds. M.A. Sweeney and E. Ben Zvi; Grand Rapids: Eerdmans, 2003), 122-61.

30 This oracle likely includes scribal elaboration, see de Jong, Isaiah Among the Ancient Near Eastern Prophets, 171-72; M. Nissinen, "Spoken, Written, Quoted and Invented: Orality and Writtenness in Ancient Near Eastern Prophecy," in Writings and Speech in Israelite and Ancient Near Eastern Prophecy, 235-72, 247-48.

31 In my opinion, the title of appiltum is more prestigious than the muhhûtum. On this question see Stökl, "The Role of Women"; idem, Prophecy in the Ancient Near East, 55. 
by Deborah, as examples of constructions of female prophets in the Hebrew Bible. ${ }^{32}$ The other female biblical prophets - Miriam, Noadiah and the female prophet from Isaiah 8:3 - will make cameo appearances in the section on Huldah. ${ }^{33}$ I have chosen to present Deborah and Huldah in their canonical order. This order has the added benefit of underlining the contrast between prophets like Innibana and Deborah.

The body of scholarly literature on female prophets in the Hebrew Bible is growing but still relatively limited in scale. Three monographs focus on female prophets, as do a significant number of individual studies. ${ }^{34}$ Much of the literature has been focused on retrieving the significance of female prophets in the Hebrew Bible. As a consequence the understanding of the term "prophet" has been very much under scrutiny, and suggestions have been made to identify characters as prophets who may not otherwise have been given that title. ${ }^{35}$ In the following I will follow the Hebrew terminology - that is, the Hebrew term - and scrutinize in which ways the texts portray the roles of women with that title.

\subsection{Deborah}

Unlike many male judges, Deborah's story is transmitted in two versions in the book of Judges. Chapter 4 contains the prose account while ch. 5 consists of a poetic account often said to be one of the oldest parts of the Hebrew Bible. ${ }^{36}$

32 The narratives about female prophets in the Hebrew Bible provide us with ample material, which means that unlike for the cuneiform texts it is not necessary to rely on a comparison with male prophets. This is not to say that in historical reality there would have been a significant difference between male and female prophets in ancient Israel and Judah. I am interested here only in the prophets' textual existence.

33 See also H. G. M. Williamson, "Prophetesses in the Hebrew Bible," in Prophecy and Prophets: Proceedings of the Oxford Old Testament Seminar, 186-92.

34 K. Butting, Prophetinnen gefragt: Die Bedeutung der Prophetinnen im Kanon aus Tora und Prophetie (Erev-Rav-Hefte. Biblisch-feministische Texte 3; Knesebeck: Erev-Rav, 2001); W. Gafney, Daughters of Miriam: Women Prophets in Ancient Israel (Minneapolis: Fortress, 2008); I. Fischer, Gotteskünderinnen: Zu einer geschlechterfairen Deutung des Phänomens der Prophetie und der Prophetinnen in der Hebräischen Bibel (Stuttgart: Kohlhammer, 2002). For a quick overview of the recent literature see Stökl, Prophecy in the Ancient Near East, 186-92.

35 See, e.g., Fischer, Gotteskünderinnen, 95-108; U. Bechmann, "Prophetische Frauen am Zweiten Tempel? Ein Vorschlag, die Töchter Zelofhads (Num 27) als Kultprophetinnen zu verstehen," BN 119-120 (2003): 52-62. To some extent the reason for this lies less in an attempt to understand ancient social roles than in the interpretation of such roles for modern ecclesiastical discussions regarding the role of women in positions of authority; see, e. g., J. Jarick, “The Seven (?) Prophetesses of the Old Testament," Lutheran Theological Journal 28 (1994): 116-21.

36 See recently, e.g., T. Notarius, The Verb in Archaic Biblical Poetry: A Discursive, Typological, and Historical Investigation of the Tense System (Studies in Semitic Languages and Linguistics 68; Leiden: Brill, 2013), 125-50. But see also dissenting voices such as, e. g., E. A. Knauf, "War 'Biblisch-Hebräisch' eine Sprache? Empirische Gesichtspunkte zur linguistischen Annäherung an die Sprache der althebräischen Literatur," ZAH 3 (1990): 11-23. My pur- 
Unlike most other biblical texts centered on female prophets, which have not been studied as extensively as other biblical texts, the appearance of great age in Judges 5 has brought it to the attention of a greater number of scholars. Many interpreters are also attracted by Deborah's powerful personality and her ability to demand respect and obedience; these features are a second aspect of the text to attract scholarly attention. Deborah is the only female judge and is also unusually involved in what is portrayed as legal decisions. In Judg 4:5 Israelites who desire משפט from her come and find her under a tree.

Deborah is referred to as a prophet in Judg 4:4, generally attributed to the Deuteronomist, where she is introduced with the otherwise unfamiliar phrase: ודבורה אשה נביאה אשת לפידות היא שפטה את ישראל בעת ההיא The The

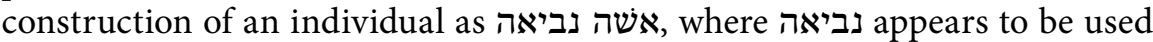
as an adjective to אשה is attested only here. The masculine equivalent appears in Judg 6:8 for an unnamed male prophet (איש נביא). Additionally, as has been noticed before, there are some structural similarities with the introduction of Huldah. ${ }^{38}$

The narrative changes sharply as soon as the introduction is over. In v. 6 , Deborah summons Barak to her and pronounces an oracle to him in which Yhwh commands Barak to mobilize ten thousand troops, to attack king Jabin and his general Sisera. Barak refuses to go on his own and demands that Deborah accompany him on the military campaign. As a consequence, Deborah foretells that a woman will kill Sisera. The following verses recount how Barak - and Deborah - move north and muster the troops. Sisera hears of their movements and in turn mobilizes his troops and moves them south. Deborah pronounces another oracle of divine support to Barak, saying that Yhwh will deliver Sisera into Barak's hands - as if she had forgotten her oracle that a woman was to kill Sisera. Yhwh confuses Sisera and his men, and Barak leads his troops to complete victory.

Verses 17-21 contain the episode that Deborah had previously foretold in v. 9: Sisera flees to Jael's tent, and she kills him with a tent-peg through his

pose in this paper is not reliant on the dating of Judg 5, most of which can exist without attribution to Deborah.

37 B. Lindars, Judges 1-5: A New Translation and Commentary (Edinburgh: T\&T Clark, 1995), 173-82. It seems likely to me that the expression אשת לפידות should be understood as "Lapidot's wife," rather than as, e.g., "a fiery woman" taking לפיד as the plural of לפידות ("torch"). The argument that Lapidot does not feature in the narrative seems to assume certain modern narrative conventions (in which only characters that play a role may appear) and seems to me to import modern literary expectations into the reading of this ancient text. In some medieval rabbinic traditions (e. g., Yalqut Šim'oni and Seder Eliyahu Rabbah), Barak is married to Deborah. This could be due to the similarity in Barak's and Lapidot's names. Additionally, the absence of Lapidot from Judg 4-5 could be 'explained' this way.

38 Williamson, "Prophetesses in the Hebrew Bible," 67-69. M. Nissinen, "Prophets and Prophecy in Joshua-Kings: A Near Eastern Perspective," in Israelite Prophecy and the Deuteronomistic History: Portrait, Reality, and the Formation of a History (eds. M. R. Jacobs and R. F. Person Jr; AIL 14; Atlanta: Society of Biblical Literature, 2013), 103-28, 103 argues that "stories of prophets span over large textual entities." 
head. Verses 22-24 round off the narrative, and one would expect chapter 5 to start with Israel having abandoned god and requiring a new judge to deliver them. Instead, we get an extended poetic composition that - from the perspective of the reader - retells the story of chapter 4 . The text is couched as a victory song sung by Barak and Deborah, praising Yhwh's intervention, which decided the battle against Sisera who is finally killed by Jael. One may well ask why Jael does not join the duo in the song, since she killed the enemy general. Deborah's character in Judges 5 is somewhat difficult to grasp. She sings a victory song - just like Miriam in Exodus 15 - and whenever Barak is mentioned, so is she. In addition she receives another title, אם בישראל ("mother in Israel"), whose precise meaning and significance escapes us. ${ }^{39}$

In the text of Judges $4-5$, then, Deborah is described as Lapidot's wife, a prophet, a judge, and "mother in Israel." She is sought out for legal decisions, she has the authority to summon Barak, she pronounces oracles to Barak, and she accompanies him into battle. Finally she and Barak jointly sing a song about the events, leaving out her oracular activity, and emphasizing Yhwh's divine intervention. Apart from her two oracles - one in direct support of Barak, the other limiting the support to some extent - the acts of summoning Barak, the military leader, and accompanying him into battle itself differentiate her from what we know about female prophets such as Innibana or any of the male and female ecstatics from Mari or from the Neo-Assyrian Empire.

\subsection{Huldah}

Huldah is introduced to readers as the wife of an otherwise unknown character, Šallum, keeper of the royal wardrobe. They live in the mišneh, Jerusalem's "Newtown" (2 Kgs 22 || 2 Chr 34). After hearing the content of the scroll which Hilkiah had found in the temple, Josiah sends a delegation of his dignitaries to the prophet Huldah. It has been argued in the past that the way that Huldah is introduced here is meant to denigrate her, but the opposite seems more likely to me: ${ }^{40}$ the intended reader would find it entirely normal for the king to

39 The connection between prophecy and music has traditionally been regarded as strong in the Hebrew Bible. The only verse that connects the two unequivocally is $2 \mathrm{Kgs} 3: 15$, but the connection between Levites, prophecy, and music in 1-2 Chronicles should also be considered in this context. Interestingly, according to Philo, the Therapeutae were also interested in music and prophetic action; see J.E. Taylor, Jewish Women Philosophers of First-Century Alexandria: Philo's Therapeutae Reconsidered (Oxford: Oxford University Press, 2006), 311-40, esp. 333-35. H. Tervanotko, “'Obey Me Like Your Mother': Deborah’s Leadership in Light of Liber Antiquitatum Biblicarum 33," JSP 24 (forthcoming), has argued that in the Liber Antiquitatum Biblicarum the term is used as a political title. Interestingly, Deborah is given this title only in chapter 5 , not in chapter 4 , where she is referred to as a prophet.

40 R. J. Weems, "Huldah, the Prophet: Reading a (Deuteronomistic) Woman's Identity," in A God So Near: Essays on Old Testament Theology in Honor of Patrick D. Miller (eds. B. A. Strawn and N. R. Bowen; Winona Lake: Eisenbrauns, 2003), 321-39; T. Ilan, "Huldah, the Deuteronomic Prophetess of the Book of Kings," lectio difficilior 1 (2010). 
send his delegation to the prophet Huldah. Huldah goes on to authenticate the scroll and to give an oracle that Josiah would die in peace.

In the past some (mainly male) scholars have argued that the king send Hilkiah to Huldah, rather than Jeremiah or Zephaniah, because she was a woman and therefore supposedly more likely to react positively to the king's request. ${ }^{41}$ While Huldah may have been positively predisposed to the Judean king, it is surely not because she was a woman. Her being a woman is noticeable to us, due to the relative absence of female prophets from the Hebrew Bible, but the ancient reader would not have thought the presence of a female prophet any more unusual than the presence of a male prophet. ${ }^{42}$

According to 2 Kgs 22, Huldah's role as a prophet is to gain divine information. Thus, she is capable of answering on Yhwh's behalf that the scroll contains a genuinely divine article of law. ${ }^{43}$ She goes on to make the prediction that Judah would be destroyed because of the behavior of Judah's leaders, but that Josiah would not witness that destruction and would die in peace because of the purity of his heart.

I share the opinion that this oracle is an indicator that the core of the narrative is likely to precede Josiah's death. Yes, he dies at home and not on the battlefield, but he dies of the wounds inflicted on him at Megiddo. It is, in my view, unlikely that anyone would have invented the oracle if they had known the way that Josiah died. ${ }^{44}$

Huldah is clearly introduced as an authority figure with a skill set available neither to King Josiah nor to the High Priest Hilkiah. The fact that she is a woman does not appear to be an issue to the author(s), either in the characterization of her, or in the oracle that she provides. ${ }^{45}$ Unlike Deborah, she is

41 On the basis of b. Meg. 14b, Rashi and Qimhi comment along these lines. I. Benzinger, Die Bücher der Könige (Kurzer Hand-Commentar zum Alten Testament 9; Freiburg: J.C. B. Mohr [Paul Siebeck], 1899), 191 and A. Šanda, Die Bücher der Könige (Exegetisches Handbuch zum Alten Testament 9; Münster: Aschendorff, 1912), 334 follow this lead, but see also more recently J. Gray, I \& II Kings: A Commentary (2d ed.; OTL; London: SCM, 1970, 726. But see already J. A. Montgomery, A Critical and Exegetical Commentary on the Books of Kings (ICC; Edinburgh: T \& T Clark, 1951), 525-26 who asks a similar question and cautiously writes: "We have to remind ourselves that judgments upon personalities and their part in history vary between that of contemporaries and that of posterity." (p. 525).

42 Nissinen, "Prophets and Prophecy in Joshua-Kings," 119. Williamson, "Prophetesses in the Hebrew Bible," 75-76, cautiously speculates that there may have been a succession of female prophets in Judah.

43 Williamson, "Prophetesses in the Hebrew Bible," 72, remarks on the (theo)logical circle that Huldah authenticates the scroll - on which her own prophetic authority is based.

44 Contra M. Pietsch, "Prophetess of Doom: Hermeneutical Reflections on the Huldah Oracle (2 Kings 22)," in Soundings in Kings: Perspectives and Methods in Contemporary Scholarship (ed. M. Leuchter and K.-P. Adam; Minneapolis: Fortress, 2010), 71-80. Naturally, this presents us with the problem that, following Deut 18, Huldah would have to be understood as a false prophet, as her word does not come true, in which case her evaluation of Hilkiah's scroll is also to be doubted.

45 While the female prophet of Isa 8:3 is a prophet in her own right (see, e.g., A. Jepsen, "Die Nebiah in Jes 8, 3," ZAW 72 [1960]: 267-68), her prophetic activity consists of giving birth 
depicted as capable of controlling her access to the deity. The king requires an oracle, and Huldah provides. However, she also appears to be working for the king by providing him with information that he requires to make the necessary decisions through her oracle(s). But she neither commands Josiah to go to war nor accompanies him to the battle as Deborah does with Barak. She does not appear to be a leader - unlike, for example - Noadiah, who is characterized as a leader of the opposition groups to Nehemiah. ${ }^{46}$ She is the king's (and Yhwh's) servant.

\section{Conclusions}

How, then, are female prophets constructed in ancient Near Eastern and biblical texts? As I have noted above, the comparison made here does not attempt to compare female prophets as they existed at Mari or in the Neo-Assyrian empire, and even less so historical female prophecy in ancient Israel and Judah. Instead it considers how authors thought of female prophets, in order to thereby get at expectations of female prophets in texts, whether ancient Near Eastern administrative letters or literary texts from the Hebrew Bible. The genre of literary predictive texts does exist in the ancient Near East, and within it we can see the literary expectation of prophets. ${ }^{47}$ However, none of the ancient Near Eastern literary predictive texts feature a female prophet; this renders comparison more difficult to make.

to the announced child. As giving birth would have been the most female of activities imaginable to ancient readers, this shows that biblical authors were capable of gendering their prophetic characters rather clearly.

46 See Neh 6:14. See, e.g., A. Brenner, The Israelite Woman: Social Role and Literary Type in Biblical Narrative (The Biblical Seminar; Sheffield: JSOT Press, 1985), 60-61; H. J. Marsman, Women in Ugarit and Israel: Their Social and Religious Position in the Context of the Ancient Near East (OtSt 49; Leiden: Brill, 2003), 564. M. Nissinen, "Das Problem der Prophetenschüler," in Houses Full of All Good Things: Essays in Memory of Timo Veijola (eds. J. Pakkala and M. Nissinen; Publications of the Finnish Exegetical Society 95: Helsinki: The Finnish Exegetical Society; Göttingen: Vandenhoeck \& Ruprecht, 2008), 337-53, mentions the possibility that female prophets provide the leadership of prophetic groups at the time (345-46). Similarly, R. P. Carroll, "Coopting the Prophets: Nehemiah and Noadiah," in Priests, Prophets and Scribes: Essays on the Formation and Heritage of Second Temple Judaism in Honour of Joseph Blenkinsopp (eds. E. C. Ulrich et al.; JSOTSup 149; Sheffield: JSOT Press, 1992), 87-99, regards female prophets as habitually in opposition to the male leadership (p. 94).

47 E.g., the Marduk Prophecy or the Uruk prophecies. See M. deJong Ellis, "Observations on Mesopotamian Oracles and Prophetic Texts: Literary and Historiographic Considerations," JCS 41 (1989): 127-86; M. Nissinen, "Neither Prophecies nor Apocalypses: The Akkadian Literary Predictive Texts," in Knowing the End From the Beginning: The Prophetic, the Apocalyptic and Their Relationships (eds. L. L. Grabbe and R.D. Haak; JSPSup 46; London: T \& T Clark, 2003), 134-48; M. Neujahr, Predicting the Past in the Ancient Near East: Mantic Historiography in Ancient Mesopotamia, Judah, and the Mediterranean World (BJS 354; Providence, R. I.: Brown University Press, 2012). 
Taking the depiction of apiltums ("spokespeople") in the texts from Mari at face value, these figures appear to be integrated into the royal administration. They provide information that the king could not otherwise access. They can be sent on missions, but only in the Epic of Zimri-Lim is a "spokesperson" attested as accompanying the king on a mission outside the kingdom. ${ }^{48}$ Deborah shares with Innibana that her oracle appears to be spontaneous. But unlike Innibana she accompanies the military leader on campaign. Huldah, in contrast appears to be integrated into the royal administration: she provides a way of accessing information from the divine, but unlike the other two female prophets studied here, she does appear to have access to the divine at her own will and is expected to have that access by her visitors (and paymasters). ${ }^{49} \mathrm{In}$ nibana, Mullissu-abu-ușri, Mullissu-kabtat, Huldah, Deborah, and other female prophets have the special ability to access information from the divine spheres, for which they were valued in their societies, or at least in the literature about them.

The cuneiform texts adduced above are, as already mentioned, administrative documents and not literary texts, with the sole exception of the Epic of Zimri Lim. ${ }^{50}$ While I do not think that administrative documents necessarily allow us an accurate image of reality, they nonetheless produce an image that ancient readers are likely to have understood as a believable reality. It is, thus, likely that male and female ancient Near Eastern prophets were valued for their ability to function as the equivalent of a loudspeaker for a deity. ${ }^{51}$ Technical diviners appear to have been valued more highly in Mesopotamian societies precisely because of their ability to access divine opinion almost at will. ${ }^{52}$

48 M. Guichard, L'épopée de Zimri-Lim (Florilegium marianum 14; Mémoires de N.A.B.U. 16; Paris: SEPOA, 2014), 21-22, 63-64, 125-27.

49 She may have been understood to have performed what is commonly called technical divination as part of her role, indicating a more fluid overlap between prophecy (as intuitive divination) and more technical forms of divination. On this aspect in the so-called Deuteronomistic History see Nissinen, "Prophets and Prophecy in Joshua-Kings," 122-23.

50 See n. 48 above.

51 The evidence with regard to provoked prophetic oracles is somewhat inconclusive. ARM 26 207 contains reference to two people (a man and a woman) being plied with some drink before the queen mother asks them questions. The syntax of the sentence is not entirely clear, so it is possible that the woman and the man are to be identified with the "signs" (ittattum) or that they are being asked regarding signs. Since the man and the woman are mentioned again in the letter without the epithet "sign," the latter appears to be the better option. In any case, no prophetic title is used in this context. On the base of the two texts regarding a ritual for Eštar (FM 32 and 3), a number of scholars think that music was used to induce trances and possibly oracles among the cult ecstatics (muhhûm) involved in the oracle. As I have shown elsewhere, however, under close reading of the available text this theory cannot be upheld; see, Stökl, Prophecy in the Ancient Near East, 211-15. The potential trance precedes the music and therefore cannot be provoked by it. All this indicates that prophecy was regarded as a means of divine-human communication initiated by the deity, whereas other forms of divination could be initiated by humans.

52 On the difference between technical and intuitive divination as I understand it, see Stökl, Prophecy in the Ancient Near East, 7-11. 
In the biblical texts regarding Deborah, Noadiah, Miriam, and the nameless prophet in Isa 8:3, there is no indication that their access to the divine was controlled by them. Instead, the deity is in control. In the case of Huldah, matters are a little different. Josiah tells his officials to "go and inquire (דרשו) of YHwh!" (2 Kgs 22:13). Huldah simply "says" (2 Kgs 22:15) her divine oracle. In the cuneiform evidence, "inquiring" of a deity is achieved through technical divination. In light of Deuteronomy's dislike of and legislation against nonprophetic forms of divine-human communication, interpreters have been hesitant to understand prophets as involved in technical forms of divination, and it is true that neither $2 \mathrm{Kgs} 22$ nor $2 \mathrm{Chr} 34$ specify how Huldah manages to have her answer to the royal inquiry ready so quickly. We could speculate that part of the attraction of Huldah in the narrative is precisely that she is able to provide the confirmatory answer when it is needed. In this, according to the data we possess, Huldah's role is closer to that of a Mesopotamian technical diviner in royal employ than to that of a Mesopotamian prophet or biblical prophet such as Miriam or Deborah. 